\title{
USE OF MOLECULAR MARKER TECHNIQUES IN SEED TESTING BY BRAZILIAN SEED COMPANIES
}

\author{
P.T. DELLA VECCHIA; C.A.R. DA SILVA; P.TERENCIANO-SOBRINHO
}

Agroflora S/A - Reflorestamento e Agropecuária, C.P. 427, CEP: 12900-000 - Bragança Paulista, SP, Brasil.

\begin{abstract}
Seed market is becoming global and globalization is growing very fast. To compete favourably in this new global seed world, quality and cost are and will be certanly the key issues. High seed quality can only be obtained by a thorough control of the entire seed production process, step by step from planning to final delivery. That requires science, technology, expertise, experience, good management and certanly, the most important, an absolute and unconditional commitment with quality. Seed testing for quality assurance is one important step in the process of production of high quality seed. In the late years a considerable amount of research has been published, particularly on the use of some Polymerase Chain Reaction DNA based new technologies (RAPD, microsatelites, AFLP) for genetic purity determinations in seed testing. As far as we know, no Brazilian seed company is using, on regular basis, RAPD or other molecular marker techniques in the determination of genetic purity in seed testing. Most of these are using morphological or physiological traits expressed by seed, seedling or mature plant and/or electrophoresis of seed or seedling proteins/isoenzymes for that purpose. Main reasons for that are: DNA molecular marker techniques are relatively new; lack of specialized personnel to run DNA molecular marker assays on routine basis; higher cost/sample when compared to proteins/ isoenzymes electrophoresis.
\end{abstract}

Key Words: molecular markers, seed testing, seed companies, genetic purity

\section{USO DE TÉCNICAS DE MARCADORES MOLECULARES NA ANÁLISE DE SEMENTES POR COMPANHIAS BRASILEIRAS PRODUTORAS DE SEMENTES.}

RESUMO: O mercado de sementes está se tornando um mercado globalizado e esta globalização está ocorrendo muito rapidamente. Para competir favoravelmente neste novo mercado global de sementes, qualidade e custo são e serão certamente os pontos chaves do negócio. Sementes de alta qualidade só podem ser obtidas através de um rigoroso controle de todo o processo de produção, etapa por etapa desde o seu planejamento inicial até a sua entrega ao consumidor final. Isto requer ciência, tecnologia, conhecimento, experiência, bom gerenciamento e certamente, o mais importante, um absoluto e incondicional comprometimento com a qualidade. Nos últimos anos, um grande número de resultados de pesquisa têm sido publicados, particularmente sobre o uso de algumas técnicas baseadas na Reação da Polimerase em Cadeia do "DNA" (RAPD, microsatélites, AFLP) para a determinação da pureza genética em análise de sementes. Tanto quanto sabemos, não existe nenhuma companhia brasileira de sementes usando, em bases regulares, RAPD ou outras técnicas de marcadores moleculares na determinação da pureza genética na análise de sementes. A maior parte delas está utilizando caracteres morfológicos ou fisiológicos expressados pelas sementes, plântulas ou plantas adultas e/ou eletroforese de proteínas/ isoenzimas de sementes ou plântulas para esta finalidade. Os principais motivos para esta realidade atual são: as técnicas para uso de marcadores moleculares baseados em DNA são relativamente novas; falta de técnicos/profissionais especializados para a utilização das mesmas, em carater de rotina; custo mais elevado/amostra quando comparado com a eletroforese de proteínas/isoenzimas.

Descritores: marcadores moleculares, análise de sementes, companhias de sementes, pureza genética

Seed market is becoming global and this globalization is growing very fast. A variety of reasons point to this direction. The World Trade Organization has been setting up and a number of regional agreements has been concluded as the European Union, Mercosur and Nafta. Developments in telecommunications and in transport are leading to the breaking down of national frontiers. The creation 
of FIS has allowed the establishment of Internal Seed Trade based on Rules and Usages and of arbitration procedures that give satisfaction for the settlement of most disputes. But perhaps the most important reason for this trend is and will be the impact of Biotechnology and as a direct consequence of it, the growing power of multinational corporations. In the past, the development of new cultivars occurred essentially in areas where the seeds were to be used. Today, even if last stages of breeding work remain dependent on local agro-climatic conditions, basic research is and will be more and more often conducted in laboratories and geographic location will probably have lesser importance in cultivar development.

In order to compete favourably in this new global seed world, Quality and Cost are and will be certainly the key issues. As there is no room for compromise with quality, creativity and good management will be the only way to lower costs.

High seed quality can be obtained only by a thorough control of the entire seed production process, step by step from planning to final delivery. That requires science, technology, expertise, experience, good management and certainly, the most important, an absolute and unconditional commitment with quality.

Seed testing for quality assurance is one important step in the process of production of high quality seed. Based on research carried out by several authors, specific seed testing protocols were set up and have been updated by ISTA. In the late years a considerable amount of research has been published, particularly on new technologies for genetic purity determinations in seed testing. Following we present a review of methodologies that have been traditionally used and the proposed new ones for determination of genetic purity in seed testing.

Traditionally, genetic purity determinations by seed companies have been carried out by the evaluation of morphological or physiological traits expressed by seed, seedlings or mature plants. McDonald (1995) emphasized that seed observations and field testing are often inaccurate because environmental stress conditions during seed or seedling/plant development can mask the expression of specific morphological or physiological traits. Besides that, the time required to grow and evaluate a large number of seed lots may be a major limitation to many seed testing laboratories, particularly if mature plants are needed for that. In spite of these difficulties, many Brazilian seed companies are still using, in some degree, morphological and/or physiological traits for determination of genetic purity. Main reason for that is the lower initial investment required to run these trials due to lack of need for laboratory facilities/ equipments and specialized personnel.

The continued release of new cultivars, particularly of $F_{1}$ hybrids, by public and private breeders in the last 20 years pressed the development of faster and more reliable new technologies for genetic purity determination. Among these is the electrophoresis of seed or seedling proteins/ isoenzymes.

Most electrophoretic systems employ either starch, polyacrylamide or agarose gels for protein/ isoenzyme separation based on molecular size and charge density. Another approach is the use of isoelectrically focused gels that separate proteins/ isoenzymes based on their position within a $\mathrm{pH}$ gradient. For more detailed information on protein/ isoenzyme electrophoresis we suggest the reading of Ohms et al. (1988); Soltis \& Soltis (1989); Alfenas et al. (1991 and 1998); Acquaah (1992); Curn (1994); Loskutov et al. (1994); Manchenko (1994); Patel (1994); Ferreira \& Gratapaglia (1996); McDonald (1995); Ji \& Zhu (1995) and Rom et al. (1995). As seed proteins/isoenzymes are products of gene expression they are considered biochemical genetic markers. Based on work carried out by several authors in the past 25 - 30 years, the electrophoresis of seed proteins/isoenzymes has been incorporated into the rules of the International Seed Testing Association and has been described in the Association of Seed Analysts' Cultivar Purity Testing Handbook (1991). According to Durig (DURIG, L.S. Product manager, WALLAC/ISOLAB - personal communication) protein/ isoenzyme electrophoresis can be successfully used in more than $80 \%$ of the cases where genetic purity determinations are required for seed testing. Most of the Brazilian seed companies, which produce $\mathrm{F}_{1}$ hybrid seeds, is using electrophoresis of seed or seedlings proteins/ isoenzymes for genetic purity determination of their seed lots.

Still, these techniques fail to differentiate a number of cultivars in some crops. That is particularly true for vegetable and flower crop cultivars were lack of protein/isoenzyme polymorphism among parental lines is often observed.

In 1990, a new genetic assay called Random Amplified Polymorphic DNA (RAPD), which is based on the Polymerase Chain Reaction conceived by Mullis \&Faloona (1987), was proposed by Welsh \& McClelland (1990) and Williams et al.(1990). For 
more detailed information on this technique we suggest the reading of Gresshoff (1994) and Ferreira \& Grattapaglia (1996). As the DNA itself is the source of polymorphism is this case, they are considered molecular genetic markers. While this technique remains relatively new, many papers have been published, in the last 5 - 8 years that gives good support to the use of RAPD for genetic purity determination in seed testing (Hashizume et al. ,1993; McDonald et al., 1995; Zhang et al., 1997). According to McDonald (1995), the use of RAPD in genetic purity testing processes the following important advantages for seed companies compared to other systems as protein electrophoresis: capability to provide greater potential discrimination of cultivars; more versatility (20 to 30 potential isoenzyme systems versus over 700 RAPD primers); practically the same general laboratory facilities/equipments and specialized personnel as for protein electrophoresis; less potential hazard to human health. Several other techniques based on the Polymerase Chain Reaction (microsatellites, AFLP, etc.) have been also proposed to genetic seed determination or fingerprinting of plant cultivars. They seem, however, more adequate to plant variety protection or patent purposes. As far as we know, no Brazilian seed company is using on regular basis RAPD or other molecular markers in the determination of genetic purity in seed testing. Main reasons for that are: the technique is relatively new; lack of specialized personnel; higher cost/sample when compared to proteins/isoenzymes electrophoresis.

\section{REFERENCES}

ACQUAAH, G. Practical protein electrophoresis for genetic research. Portland: Dioscorides Press, 1992. $131 \mathrm{p}$.

ALFENAS, A.C. Eletroforese de proteínas e isoenzimas de fungos e essências florestais. Viçosa: Universidade Federal de Viçosa, 1991. 242 p.

ALFENAS, A.C. et al. Eletroforese de isoenzimas e proteínas afins: fundamentos e aplicações em plantas e microorganismos. Viçosa: Universidade Federal de Viçosa, 1998. 574p.

ASSOCIATION OF OFFICIAL SEED ANALYSTS. Cultivar purity testing handbook: contribuition number 33. 1991. 78p.
CURN, V. Isozymes of acid phosphatase and leucine aminopeptidase as biochemical markers for purity testing in rapeseed androgenetic lines. Scientia Agriculturae Bohemica, v.25, n.2, p.117-126, 1994.

FERREIRA, M.E.; GRATTAPAGLIA, D. Introdução ao uso de marcadores moleculares em análise genética. Brasília: EMBRAPA/CENARGEN, 1996. 220 p.

GRESSHOFF, P.M. Plant genome analysis. Boca Raton: CRC Press, 1994. 247p.

HASHIZUME, T.; SATO, P.; HIRAI, M. Determination of genetic purity of hybrid seed in watermelon (Citrullus lanatus) and tomato (Lycopersicon esculentum) using random amplified polymorphic DNA (RAPD). Japanese Journal of Breeding, v.43, n.3, p.367-375, 1993.

JI, Y.B.; ZHU, Q.J. Application of isozyme electrophoresis to determine the cultivar purity of cucumber $\mathrm{F}_{1}$ hybrid seeds. Acta Horticulturae Sinica, v.22, n.3, p.251-255, 1995.

LOSKUTOV, A.; DEMURIN, Y.; OBRAZTSOU, I. et al. Isozymes, tocopherols and fatty acids as seed biochemical markers of genetic purity in sunflower. Helia, v. 17, n.21, p.5-10, 1994.

MANCHENKO, G.P. Handbook of detection of enzymes on electrophoresis gels. Boca Raton: CRC Press, 1994. 341p.

McDONALD, M.B. Genetic purity: from protein electrophoresis to RAPDs. In: THE FIFTIETH ANNUAL CORN \& SORGHUM INDUSTRY RESEARCH CONFERENCE 1995. Proceedings, 1995. p.256-271.

MULLIS, K.; FALOONA, F. Specific synthesis of DNA in vitro via a polymerase catalysed chain reaction. Methods in Enzimology, v.55, p. 335-350.

OHMS, J.P. et al. Determination of seed purity of hybrid wheat varieties using electrophoresis of seed proteins. In: The 99th VDLUFA Congress, 1987. Proceedings, 1988. p.757-764.

PATEL, D. Gel Electrophoresis: essential data series. Chichester: John Wiley \& Sons, 1994. 137p. 
ROM, M.; BAR, M.; ROM, A. et al. Purity control of $F_{1}$ hybrid tomato cultivars by RAPD markers. Plant Breeding, v.114, n.2, p.188-190, 1995.

SOLTIS, D.E. \& SOLTIS, P.S. Isozymes in plant biology. Portland: Dioscorides Press, 1989. 268p.

WELSH, J.I.; MCCLELLAND, M. Fingerprinting genomes using PCR with arbitrary primers. Nucleic Acids Research, v.18, p.7213-7218, 1990.

WILLIAMS,J.G.; McDONNALD, M.B.; SWEENEY, P.M. et al. DNA polymorphism amplified by arbitrary primers are useful as genetic marker. Nucleic Acid Research, v.18, p.6531-6535, 1990.
ZHANG, J.; KUBELIK, A.R.; LIVAK, K.J. et al. Testing for genetic purity in petunia and cyclamen seed using random amplified polymorphic DNA markers. HortScience, v.32, n.2, p.246-247, 1997.

Recebido para publicação em 15/07/98 Aceito para publicação em 03/08/98 